\title{
Anonymous in Life, Anonymous in Death: Memoirs and Biographies of Administrators
}

\section{John Nethercote}

This essay has two objectives: the first is to provide a tour d'horizon of biographies and autobiographies of administrators. Its second purpose is to comment on the utility of biography as a method of studying administration and its contribution to government.

In comparison with political leaders and the more public figures in government and politics, Australian administrators are not well-served by biographies, even in the brief form found in the Australian Dictionary of Biography. There is a great reluctance to engage with these officials as 'subjects' for biography and reluctance among officials to consider writing autobiographical memoirs. This is true elsewhere. If we examine British history, it is well-known that Sir Geoffrey Elton, the doyen of Tudor studies, notoriously refused to write a biography of Thomas Cromwell, the minister-bureaucrat behind such a great event as the Reformation in England, although Elton's contemporary, A.G. Dickens, eventually undertook the task in a volume still worth reading (1959).

There is no biography of the legendary founder of the modern British civil service, Sir Charles Trevelyan. Bare details of his career may be found in the $O D N B$, and some of his accomplishments in Maurice Wright's classic, Treasury control of the Civil Service, 1854-1874 (1969). To learn about Trevelyan's character readers must go to Trollope's Three Clerks,(2004 [1858]) where he appears as 'Sir Gregory Hardlines'. The authenticity of the novelist's portrait is attested by Lady Trevelyan, who confided to Trollope that in her home they sometimes referred to Sir Charles as 'Sir Gregory'. Trevelyan's great twentieth century counterpart, Sir Warren Fisher, is one of the few administrators to have hurdled the biographical barrier.

In the mid-twentieth century, there are a host of books on Winston Churchill especially on the conduct of his war-time prime ministership. But virtually missing from most of these endeavours is the civilian support for Churchill during those years provided by Sir Edward Bridges, though his contribution was immense. Bridges' role in government has been only selectively addressed (Chapman 1988).

By contrast, the most famous administrator in British history, Samuel Pepys, has had more books - and generally better books — written about him than all 
Australian prime ministers put together. Pepys's own diaries run to ten volumes and cover only the decade of the 1660s.

In Australia there is a small library of biographies and autobiographies about and by officials from the foreign and defence services. Among heads of Foreign Affairs, apart from Peter Edwards' life of Sir Arthur Tange (2006), and Sir Arthur's own memoirs (1996), there have been autobiographies from Sir Alan Watt (1972), Alan Renouf (1980), Peter Henderson (1986), and Richard Woolcott (2003) as well as several ambassadors - Alf Stirling (1973), Jim Cumes (1988) and Ralph Harry (1983). Fin Crisp wrote an insightful recollection of his friend Sir Peter Heydon, Secretary of Immigration, 1960-71 (1972), and a biography of Sir James Plimsoll is in preparation. David Horner has composed a major study of Sir Frederick Shedden, head of Defence from the mid-1930s to the mid-1950s (2000).

Otherwise Australia's main administrative biographical studies of are of two veterans - H.C. 'Nugget' Coombs and John Crawford - from the Department of Postwar Reconstruction, an organisation with a considerable reputation in its day and since for self-publicity.

Among the notable autobiographical memoirs, sometimes revealing in ways the authors may not have intended, are Coombs's Trial Balance (1981), Robert Garran's Prosper the Commonwealth (1958), Sir William Dunk's They Also Serve (1974), John Menadue's Things You Learn Along the Way (1999) and Alf Rattigan's Industry Assistance: The inside story (1986).

The most pronounced gaps on the administrative biography shelf are Sir Robert Garran and Sir Roland Wilson. Garran was unquestionably the major figure in administration in the first three decades of the Commonwealth and his influence extended well beyond the field of law to imperial and international relations, the workings of the federation, the structure of the public service and the ever-vexatious field of industrial relations. Sir Roland Wilson was instrumental in the development, at a critical time, of three major institutions of Australian government - the Australian Bureau of Statistics, the Department of Labour and National Service (now the Department of Employment and Workplace Relations), and the Treasury (including the Department of Finance). As a long-serving board member of the Commonwealth Bank, the Reserve Bank and QANTAS, including extended periods as chairman of two of them, he was a major contributor to the practice of public enterprise in Australia's Keynesian era. Not only is there not a scholarly biography of Roland Wilson, for reasons (it has been said) of caprice he was not even the subject of an essay in the Reserve Bank-funded book on leading financiers in Australia, though few had greater claims to a place than he.

For administrators, it seems that that badge of their profession, anonymity, follows them not only in their 'official life' and in retirement but also in death. 
Yet administrators and their institutions have played an integral part in Australia's history. The testimony of Second World War historian, Sir Paul Hasluck, is instructive:

In writing the civil volumes of the official war history I took the view that the person who bears the political responsibility for action should be credited with having taken the action. Now, in a more personal account of the war years, I take the liberty of passing on most of the credit for war-time administration to the senior public servants.

... looking only at its daily administration a few public servants carried the burden nobly almost in spite of their ministers. The war effort was managed to a large extent by them.

Their 'life studies' would be valuable and should be encouraged. Johnson's dictum should be recalled: that 'there has rarely passed a life of which a judicious and faithful narrative would not be useful'. In Johnson's view, knowledge of 'mistakes and miscarriages, escapes and expedients' are likely to be 'of immediate and, apparent use'. Acknowledging the value of life studies, however, still leaves open questions of form, length and scope. Donne's precept, that no man is an island unto himself, applies with greater force to administrators than politicians and many other professions.

Administration is quintessentially a collegial activity - though the collegiality will often be exceedingly competitive (see Hasluck 1980: 159). In the past as in the present there are few opportunities for an administrator to place an individual stamp on a policy or an institution. Because of his youth, and the fact that he was present at the creation of Federation, Garran had an unusual career; nonetheless, for the first decade and a half of his long secretaryship in the Attorney-General's Department, it would be necessary to give due weight to the influence of other comparable figures, Atlee Hunt, at External Affairs, Woolaston at Trade and Customs, and the mighty Duncan McLachlan, the inaugural Public Service Commissioner. But by the Second World War and the subsequent periods of reconstruction, affluence and prosperity, it is difficult for any one individual to claim an uncontested ascendancy. To focus on an individual may well prove to be an act of considerable distortion at several levels, including of the subject individual.

While many officials (and, indeed, politicians) are worthy of study, few warrant an 80,000 word monograph. Quite a number, however, justify more than the thousand or so words for which they might qualify if selected for an entry in the Australian Dictionary of Biography .

In the case of officialdom, there is a strong argument for greater use of the essay as the principal form of biography. The essay has an honourable place in the history of biography. It was essentially the form used by the Roman chronicler 
Suetonius in The Twelve Caesars and Plutarch in the Parallel Lives. During the nineteenth century both Macaulay and Walter Bagehot resorted to the essay for numerous biographical studies. In our own time, extended reviews of biographical studies — published in, say, the New York Review of Books follow in the punchy essay-style of Macaulay (partly derivative and partly commentary).

The essay is also ideal for accommodating the collegial character of politics, government and administration, and here there are also a range of precedents from John Aubrey's Brief Lives (1965) and William Hazlitt's The Spirit of the Age (1923) which, in fact, commences with a portrait of that sage of modern government, Jeremy Bentham, to Lytton Strachey's Eminent Victorians (1948). More recent examples of this form are Richard Hofstader's American Political Tradition and the Men Who made it and Hugo Young's account of Britain's relationship with the European Union, This Blessed Plot, built around a story of a dozen or so of principal individuals.

A different approach but still with a strong biographical flavour was used by the Canadian historian, J.L. Granatstein in The Ottawa Men: The civil service mandarins (1982), the story of the senior public service of Canada in the Second World War and the post-war period.

An alternative way to study Australia's post-war history would be to commission a volume entitled 'The Rise and Fall of Keynesianism in Australia', composed of essays on among others, Giblin, Copland, McFarlane, Wilson, Bailey, Coombs, Crawford, Bland, Westerman, Randall, Rattigan, Wheeler and Stone. Such an approach would furnish a more rounded picture of the rhythms of the time as well as the contest of ideas in a manner which usually proves very difficult for a biography of any single individual. Likewise, while few of Australia's diplomats justify (or can sustain) a full-scale biography, it is not hard to see the scope for a similarly illuminating volume on a number of the leading figures responsible in the generation after the Second World War for establishing Australia's relations with the nations of Asia. 